\title{
MARINE RESERVOIR CORRECTIONS: ST. HELENA, SOUTH ATLANTIC OCEAN
}

\author{
Colin A Lewis ${ }^{1}$ Paula J Reimer ${ }^{2} \bullet$ Ron W Reimer $^{2}$
}

ABSTRACT. We present the first marine reservoir age and $\Delta \mathrm{R}$ determination for the island of St. Helena using marine mollusk radiocarbon dates obtained from an historical context of known age. This represents the first marine reservoir age and $\Delta R$ determination in the southern Atlantic Ocean within thousands of kilometers of the island. The depletion of ${ }^{14} \mathrm{C}$ in the shells indicates a rather larger reservoir age for that portion of the surface Atlantic than models indicate. The implication is that upwelling old water along the Namibian coast is transported for a considerable distance, although it is likely to be variable on a decadal timescale. An artilleryman's button, together with other artifacts found in a midden, demonstrate association of the mollusk shells with a narrow historic period of AD 1815-1835.

\section{INTRODUCTION}

Regional marine radiocarbon reservoir corrections are necessary for calibration of ${ }^{14} \mathrm{C}$ ages of marine samples such as foraminifera and mollusk shells. To estimate past reservoir corrections, it is necessary to use marine samples of known age collected prior to the increase in atmospheric ${ }^{14} \mathrm{C}$ due to nuclear weapons testing ( AD 1955-1964) and its subsequent distribution in the ocean. However, such material in the southeastern Atlantic is extremely scarce. General circulation models have been used to attempt to predict surface ocean reservoir ages (Butzin et al. 2005) but are unlikely to capture differences due to regional currents or upwelling. In this study, we measure ${ }^{14} \mathrm{C}$ in pre-1955 mollusks collected from a midden deposit on the island of St. Helena, which is located at $15^{\circ} 58^{\prime} \mathrm{S}$, $5^{\circ} 43^{\prime} \mathrm{W}$, in the Sub-Atlantic Anticyclonic (SAA) gyre of the southern Atlantic Ocean (Figure 1).

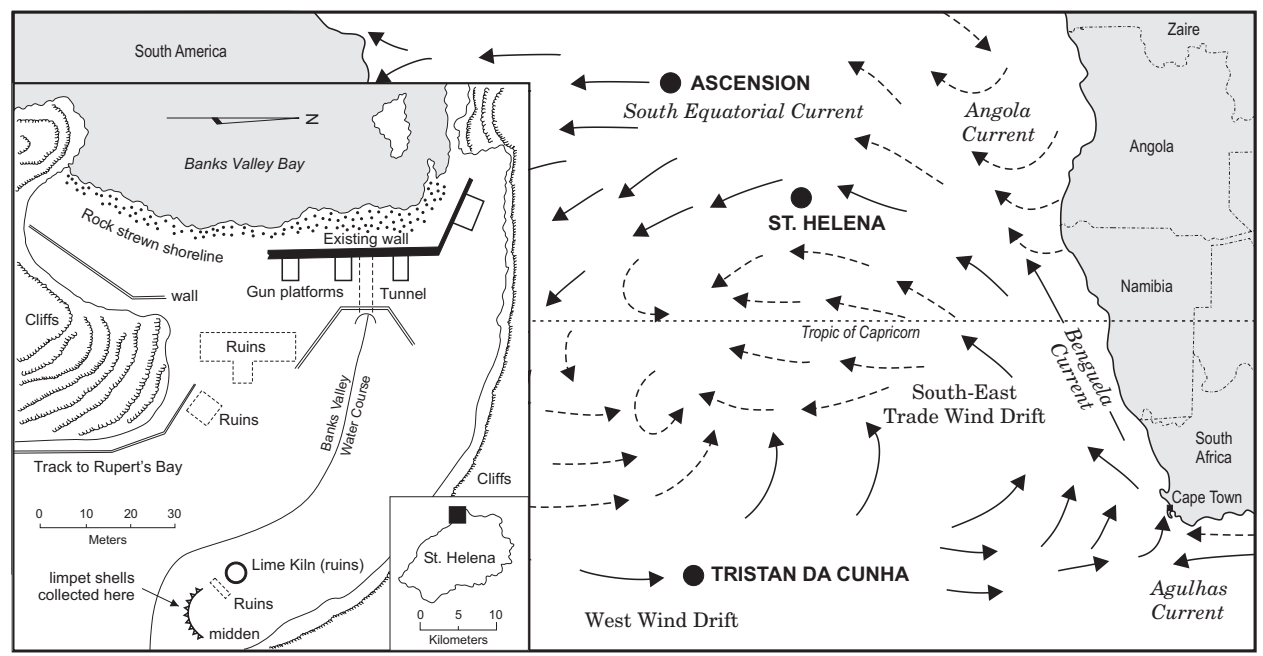

Figure 1 The general circulation of surface waters in the South Atlantic Ocean in January. Dashed arrows indicate currents of 25-50\% constancy; solid arrows indicate currents of 51-74\% constancy (Edwards 1990). The only previous $\Delta \mathrm{R}$ evaluation $\left(224 \pm 51{ }^{14} \mathrm{C}\right.$ yr) for this region is from near Cape Town, South Africa (Southon et al. 2002). Inset (based on Denholm 1990) is a map of Banks Valley showing the position of the lime kiln and midden. A further inset shows the position of Banks Valley in relation to St. Helena. North is to the top of the maps except where shown on the inset of Banks Valley.

\footnotetext{
${ }^{1}$ Geography Department, Rhodes University, Grahamstown 6140, South Africa. Corresponding author: C.Lewis@ ru.ac.za. ${ }^{2}$ School of Archaeology and Palaeoecology, ${ }^{14} \mathrm{CHRONO}$ Centre for Climate, the Environment \& Chronology, Queen's University Belfast, Belfast BT7 1NN, United Kingdom.
} 


\section{METHODS}

Three shells of Patella caerulea (blue limpet) were collected from a midden adjacent to the remains of an artificial platform beside and up valley from a disused and now ruined lime kiln in Banks Valley $\left(15^{\circ} 54^{\prime} \mathrm{S}, 5^{\circ} 42^{\prime} \mathrm{W}\right)$ on the island of St. Helena in March 2007 (Figure 2).

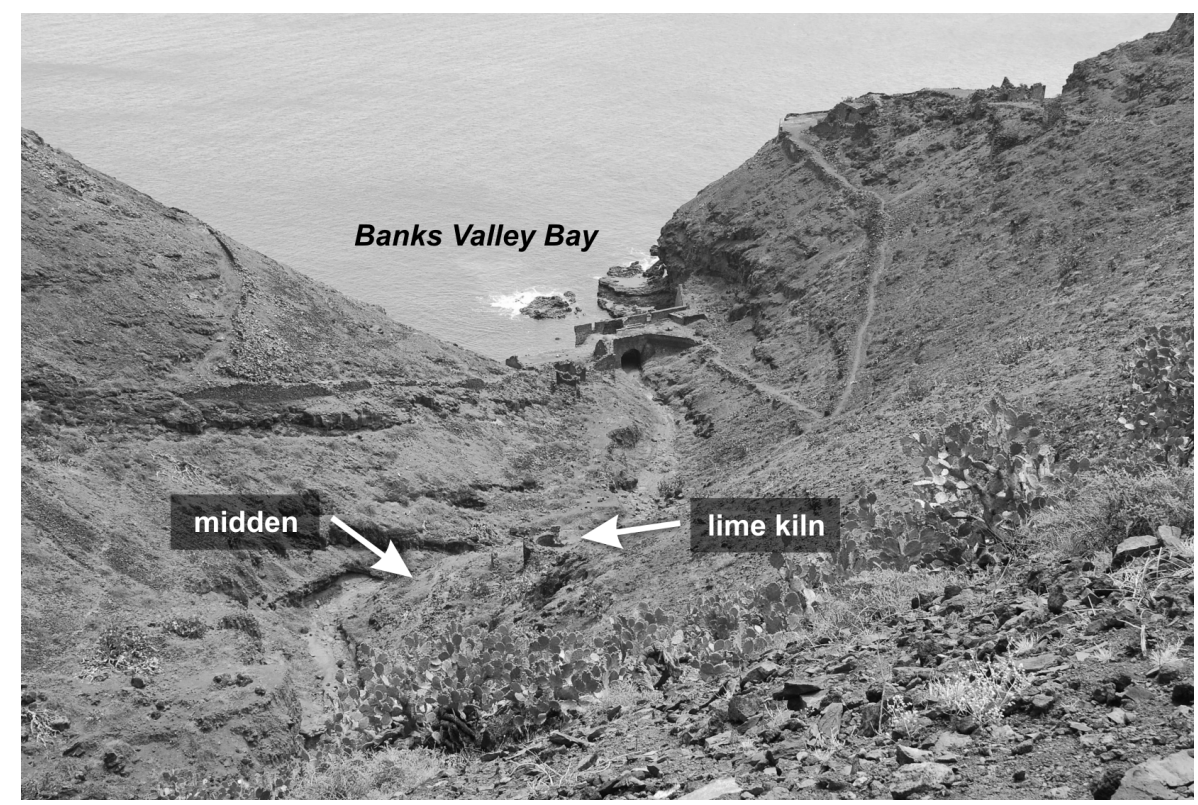

Figure 2 Photograph of the lime kiln and midden and the fortifications and rock-cut platform (including island) at Banks Valley Bay, looking westward.

Melliss (1875) reported that Patella caerulea were "found plentifully alive and sticking to the rocks on the sea-coast about high-water mark." Patella caerulea are edible, and Basil George (personal communication, 2007), who drew attention to the site, stated that people on St. Helena used to collect and eat them to supplement their diet. The midden from which the shells were collected is located about $100 \mathrm{~m}$ upstream from the coast of Banks Valley Bay, where there is a rock-strewn shoreline at the head of the bay and a rock-cut platform on either side of the bay, both of which provide suitable environments for Patella caerulea.

The lime kiln was built following the discovery in 1797 of calcareous sands in the headwaters of Banks Valley that were suitable for lime production (St. Helena Letters to England, 21 August 1797). These sands are believed to have been derived from deposits on the presently submerged shelf that surrounds St. Helena, and are thought to have been blown onshore during times of low sea level (Muir and Baker 1968; Nunn 1984; Ashmole and Ashmole 2000). They comprise mainly shelly particles resulting from the deposition of a submarine faunal assemblage that was reworked and comminuted by wave action when the sea advanced and retreated (probably on numerous occasions) across that shelf. The sands include particles of Eponides sp., Rotalia sp., Asterigerina sp., Heterostegina sp., Ciadaris sp. spines (abraded), Amphistegina sp., Quinqueloculina sp., Gastropoda $10 \mathrm{sp.,} \mathrm{Polyzoa} 5 \mathrm{sp}$., and fragments of lamellibranchs, scleractinian corals, ophiuroid sclerites, and serpulid worm tubes, indicative of a warm, shallow water subtropical or tropical fauna of Miocene to Recent age (Baker 1968). Lime was produced from these calcareous sands at Banks Val- 
ley by 1800 (St. Helena Records, 95, 30 June 1800), but production had ceased before 1835 (St. Helena Commission of 1835, Report, page 429).

The midden spills downslope from the platform, towards the ephemeral stream that drains Banks Valley. One limpet shell partially projected from fuel remnants that there formed the sloping front of the midden that faced the stream (Figure 3). The fuel appeared to be some kind of low-grade coal or coke. Excavation into the midden at that same level $(\sim 8 \mathrm{~cm})$ uncovered other similar shells and fuel remnants, as well as pieces of broken blue-patterned china typical of that of Chinese origin imported into St. Helena in the 18th and early 19th centuries. Elsewhere in the midden, the stems of clay pipes-such as smokers used in the 18th and 19th centuries-were uncovered, as was a button of the St. Helena Artillery. The inference is that limpet shells, broken domestic china, and broken clay pipes were thrown onto the midden and an artilleryman (or someone else wearing an Artillery uniform) had the misfortune to lose a button, which also became incorporated in the midden.

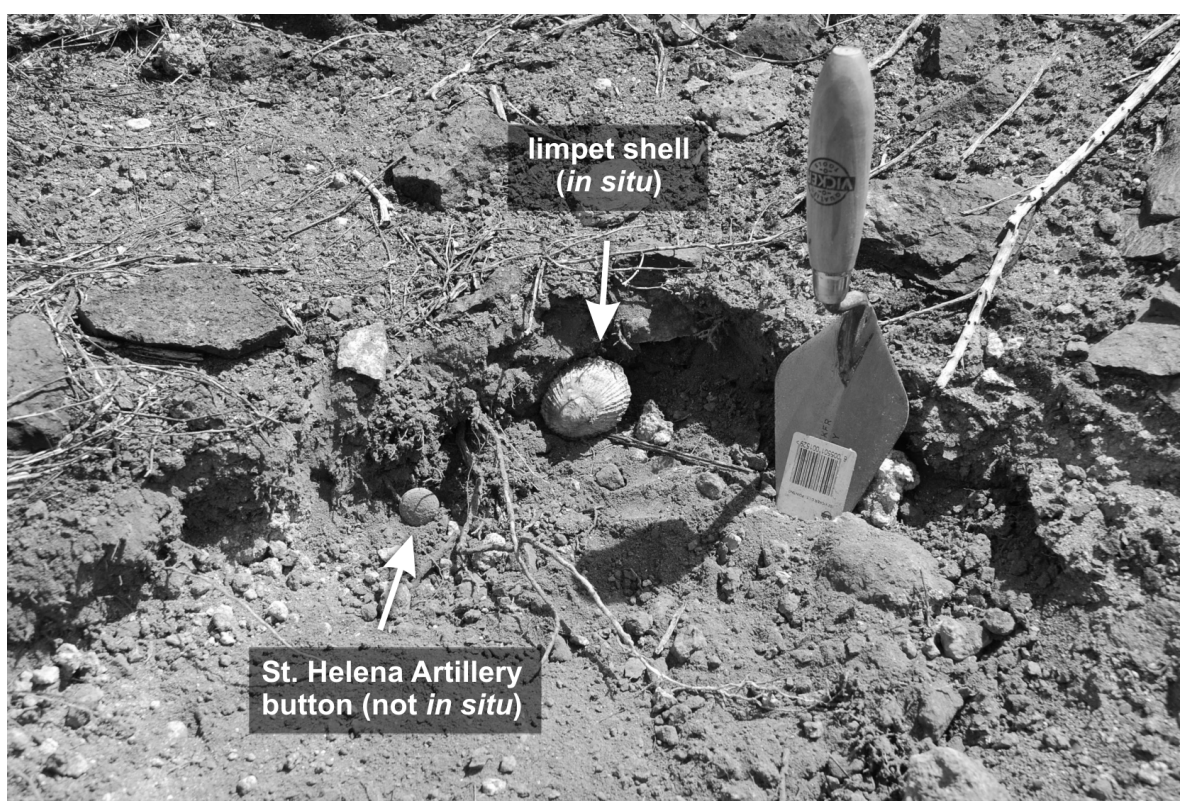

Figure 3 Photograph of the sloping front of the midden with one of the limpet shells in situ and an artillery button (not in situ) that was discovered elsewhere in the midden.

An untitled and unpublished typescript in the St. Helena Archives, dated 1 October 1991 and signed "Custodian of Records" (who was then Robert Maggott), states that during the captivity of Napoleon on the island (1815-1821; Gosse 1938), the "St. Helena Foot and St. Helena Artillery [was] formed. These men were domiciled in England on their way home on leave from India." If Maggot was correct, these were not the St. Helena Infantry and St. Helena Artillery regiments of the English East India Company that had fought with distinction at the capture of Cape Town in 1795 (Kitching 1947). Both Kitching and Maggott state that the St. Helena Artillery was disbanded in 1836.

Documentary evidence shows that lime was produced at Banks Valley after 1797, but that production had ceased before 1835 . The shells of edible limpets discarded on the midden associated with the lime kiln are therefore unlikely to have been deposited outside the period 1797-1835. The presence of a button of the St. Helena Artillery in the midden, from which shells of Patella caerulea 
were collected in 2007 , indicates that soldiers and/or workers associated with the production of lime collected and ate limpets, discarding their shells on the midden between 1815 (when the St. Helena Artillery was formed) and an unknown time before 1835 , by when lime production had ceased in Banks Valley. The limpets whose shells were analyzed were therefore probably detached from the coastal rocks, their flesh eaten, and their shells discarded on the midden between 1815 and 1835 .

\section{RADIOCARBON METHODS}

The shell samples were etched with $1 \% \mathrm{HCl}$ to remove approximately $25 \%$ of the initial weight, and then hydrolyzed to $\mathrm{CO}_{2}$ with phosphoric acid. The $\mathrm{CO}_{2}$ was converted to graphite on an iron catalyst using the zinc reduction method (Slota et al. 1987; Hua et al. 2001; Mueller and Muzikar 2002). The ${ }^{14} \mathrm{C} /{ }^{12} \mathrm{C}$ and ${ }^{13} \mathrm{C} /{ }^{12} \mathrm{C}$ ratios were measured by accelerator mass spectrometry (AMS) at the ${ }^{14} \mathrm{CHRONO}$ Centre, Queen's University Belfast. The ${ }^{14} \mathrm{C}$ age and 1 standard deviation were calculated using the Libby half-life of $5568 \mathrm{yr}$ following the conventions of Stuiver and Polach (1977). The ages were corrected for isotope fractionation using the AMS-measured $\delta^{13} \mathrm{C}$ (not given), which accounts for both natural and machine fractionation.

The reservoir age $R$ and the regional offset $\Delta \mathrm{R}$ were calculated from the difference between the ${ }^{14} \mathrm{C}$ age of the shells, and the average age and variance for the calendar period from the atmosphere and the global ocean, respectively, using the calibration curves IntCal04 (Reimer et al. 2004) and Marine04 (Hughen et al. 2004).

\section{RESULTS}

The results of the AMS ${ }^{14} \mathrm{C}$ measurements are given in Table 1 . The pooled mean ${ }^{14} \mathrm{C}$ age of the 3 limpets was $829 \pm 18 \mathrm{BP}\left(T^{\prime}=1.72, \chi^{2}{ }_{0.05}=5.99\right.$ [Ward and Wilson 1978]). The uncertainty in the reservoir age includes the uncertainty in the atmospheric curve, but for $\Delta \mathrm{R}$ the uncertainty of the marine curve is not included, since this is done in the calibration process. For the more conservative calendar age estimate of the shells of AD $1797-1836$, we calculate a $R$ of $697 \pm 43{ }^{14} \mathrm{C}$ yr and a $\Delta \mathrm{R}$ value of $311 \pm 18{ }^{14} \mathrm{C}$ yr. If we take the more probable age for the samples to be between $\mathrm{AD} 1816$ and 1836 , this gives a $R$ of $725 \pm 19{ }^{14} \mathrm{C}$ yr and $\Delta \mathrm{R}$ of $325 \pm 18{ }^{14} \mathrm{C} \mathrm{yr}$.

Table 1 Conventional ${ }^{14} \mathrm{C}$ ages and the pooled mean age for the limpet shells.

\begin{tabular}{lll}
\hline UBA-nr & Sample ID & ${ }^{14} \mathrm{C} \mathrm{BP}$ \\
\hline 7852 & StH-Limpet1 & $875 \pm 54$ \\
7853 & StH-Limpet2 & $808 \pm 25$ \\
7854 & StH-Limpet3 & $844 \pm 28$ \\
& Pooled mean ${ }^{\mathrm{a}}$ & $829 \pm 18$ \\
\hline
\end{tabular}

${ }^{\mathrm{a}} T^{\prime}=1.72, \chi^{2}{ }_{0.05}=5.99$.

\section{DISCUSSION}

Our results show a reservoir effect for St. Helena nearly 300 yr larger than the average global surface ocean $\sim 400{ }^{14} \mathrm{C}$ yr and the pre-industrial reservoir age of $376 \mathrm{yr}$, interpolated from the model of Butzin et al. (2005) using the Web site of Fairbanks (2007).

The shells used in this study are from the herbivorous mollusk Patella caerulea, which feeds by scraping algae off rocks and plants. Anomalous reservoir ages have been observed for herbivorous mollusks in areas of limestone substrate and estuarine environments (Dye 1994; Hogg et al. 1998). Because a portion of the shell carbonate in some mollusks is derived from metabolic sources 
(Tanaka et al. 1986; Dettman et al. 1999), $\Delta \mathrm{R}$ might also be variable even when the local geology is volcanic due to ingestion of seaweed that continues to photosynthesize at low tide using atmospheric $\mathrm{CO}_{2}$ (Cook et al. 2004). Such an effect would be evidenced by lower values of $\Delta \mathrm{R}$. The island of St. Helena is of volcanic origin (Baker 1968), although surrounded by a submerged shelf that is at least partly covered with calcareous sands, as described earlier in this paper. The limpet's natural environment would have been the rocky shoreline at the head of the bay or the rock-cut platforms. The ingestion of calcareous sand is highly unlikely to have contributed to the reservoir age of the limpets in this study. Therefore, we must look at the ocean currents to explain the large reservoir age.

The dominant ocean current in the region of St. Helena is the South-East Trade Wind Drift (SET; Edwards 1990), which is fed primarily by the Benguela Current. The latter is the eastern boundary current of the South Atlantic subtropical gyre. It begins as a northward flow off the Cape of Good Hope, where it skirts the western African coast equatorward until around $24-30^{\circ} \mathrm{S}$. Here, most of it separates from the coast as it bends toward the northwest. The prevailing winds are responsible for strong Ekman transport and the resulting coastal upwelling of cool, nutrient-rich water.

Our results suggest a larger component of old, deep water than is evident from the measurement ( $\Delta \mathrm{R}=224 \pm 51{ }^{14} \mathrm{C}$ yr) by Southon et al. (2002) from a mollusk shell (Venerupis corrugate) from the Cape of Good Hope, located in the region of the Agulhas Current. We attribute the apparent age of our specimens to upwelled old Atlantic water along the Namibian coastline, which has been transported to St. Helena by the southeast tradewinds that drive the Benguela Current. This wind system results from gradients in air pressure between the South Atlantic Anticyclone (SAA) and the low pressure of the Intertropical Convergence Zone (ITCZ) in the north and those between the SAA and the Angola-Kalahari Low in the east. Changes in position and intensity of these atmospheric centers cause variability in the SET (Feistel et al. 2003). Hence, we expect that the degree of upwelling and the area affected are likely variable (Hagen et al. 2005). Nevertheless, our results point out a potentially large reservoir effect for marine samples from this region.

\section{ACKNOWLEDGMENTS}

Mr Basil George is thanked for drawing attention to the site and for information on the use of limpet meat; the librarians and archivists in Jamestown, especially Ms Lacosta McDaniel and Mr Ricky Fowler, for aid with documentary research; His Excellency the Governor of St. Helena for permitting this research; Ms Bronwyn Mclean for cartographic work; and Rhodes University for financial support that made the collection of shells possible. We also thank Dr Fiona Petchey for valuable comments on the paper.

\section{REFERENCES}

Ashmole P, Ashmole M. 2000. St. Helena and Ascension Island: A Natural History. Oswestry: Anthony Nelson. $475 \mathrm{p}$

Baker I. 1968. The geology of Saint Helena Island, South Atlantic [unpublished $\mathrm{PhD}$ dissertation]. London: University of London. 396 p.

Butzin M, Prange M, Lohmann G. 2005. Radiocarbon simulations for the glacial ocean: the effects of wind stress, Southern Ocean sea ice and Heinrich events. Earth and Planetary Science Letters 235(1-2):45-61.

Cook GT, MacKenzie AB, Muir GKP, Mackie G Gulliver P. 2004. Sellafield-derived anthropogenic
${ }^{14} \mathrm{C}$ in the marine intertidal environment of the $\mathrm{NE}$ Irish Sea. Radiocarbon 46(2):877-83.

Denholm K. 1990. St. Helena, South Atlantic fortress. Fortress 6:11-23.

Dettman DL, Reische AK, Lohmann KC. 1999. Controls on the stable isotope composition of seasonal growth bands in aragonitic fresh-water bivalves (unionidae). Geochimica et Cosmochimica Acta 63(7-8):1049-57.

Dye T. 1994. Apparent ages of marine shells: implications for archaeological dating in Hawai'i. Radiocarbon 36(1):51-7.

Edwards A. 1990. Fish and Fisheries of Saint Helena Is- 
land. Newcastle upon Tyne: Centre for Tropical Coastal Management Studies, University of Newcastle upon Tyne. $152 \mathrm{p}$.

Fairbanks R. 2007. URL: http://radiocarbon.LDEO.columbia.edu/. Accessed 31 December 2007.

Feistel R, Hagen E, Grant K. 2003. Climatic changes in the subtropical Southeast Atlantic: the St. Helena Island Climate Index (1893-1999). Progress in Oceanography 59(2-3):321-37.

Gosse P. 1938. St. Helena 1502-1938. London: Cassell and Co. $446 \mathrm{p}$.

Hagen E, Agenbag JJ, Feistel R. 2005. The winter St. Helena climate index and extreme Benguela upwelling. Journal of Marine Systems 57(3-4):219-30.

Hogg AG, Higham TFG, Dahm J. 1998. ${ }^{14} \mathrm{C}$ dating of modern marine and estuarine shellfish. Radiocarbon 40(2):975-84.

Hua Q, Jacobsen GE, Zoppi U, Lawson EM, Williams AA, Smith AM, McGann MJ. 2001. Progress in radiocarbon target preparation at the ANTARES AMS Centre. Radiocarbon 43(2A):275-82.

Hughen KA, Baillie MGL, Bard E, Beck JW, Bertrand CJH, Blackwell PG, Buck CE, Burr GS, Cutler KB, Damon PE, Edwards RL, Fairbanks RG, Friedrich M, Guilderson TP, Kromer B, McCormac G, Manning S, Bronk Ramsey C, Reimer PJ, Reimer RW, Remmele S, Southon JR, Stuiver M, Talamo S, Taylor FW, van der Plicht J, Weyhenmeyer CE. 2004. Marine04 marine radiocarbon age calibration, $0-26 \mathrm{cal} \mathrm{kyr} \mathrm{BP}$. $R a-$ diocarbon 46(3): 1059-86.

Kitching GC. 1947. The St. Helena regiments of the East India Company. Army Historical Research 25:2-8.

Maggott R. 1991. Untitled and unpublished typescript dated 1 October 1991. Filed in The Archives, The Castle, Jamestown, St. Helena.

Melliss JC. 1875. St. Helena: A Physical and Topographical Description of the Island. Ashford: L Reeve and Co. $426 \mathrm{p}$.
Mueller K, Muzikar P. 2002. Correcting for contamination in AMS ${ }^{14} \mathrm{C}$ dating. Radiocarbon 44(2):591-5.

Muir MD, Baker I. 1968. The early Pliocene flora of St. Helena. Palaeogeography, Palaeoclimatology, Palaeoecology 5(3):251-68.

Nunn PD. 1984 Evidence for late Quaternary sea level change around St. Helena island, South Atlantic. Catena 11(2-3):187-95.

Reimer PJ, Baillie MGL, Bard E, Bayliss A, Beck JW, Bertrand CJH, Blackwell PG, Buck CE, Burr GS, Cutler KB, Damon PE, Edwards RL, Fairbanks RG, Friedrich M, Guilderson TP, Hogg AG, Hughen KA, Kromer B, McCormac G, Manning S, Bronk Ramsey C, Reimer RW, Remmele S, Southon JR, Stuiver M, Talamo S, Taylor FW, van der Plicht J, Weyhenmeyer CE. 2004. IntCa104 terrestrial radiocarbon age calibration, 0-26 cal kyr BP. Radiocarbon 46(3):1029-58.

Slota Jr PJ, Jull AJT, Linick TW, Toolin LJ. 1987. Preparation of small samples for ${ }^{14} \mathrm{C}$ accelerator targets by catalytic reduction of CO. Radiocarbon 29(2):303-6.

Southon J, Kashgarian M, Fontugne M, Metivier B, Yim WW-S. 2002. Marine reservoir corrections for the Indian Ocean and southeast Asia. Radiocarbon 44(1): 167-80.

St. Helena Commission of 1835, Report. Photocopy in The Archives, The Castle, Jamestown, St. Helena.

St. Helena Letters to England. Manuscript copies in The Archives, The Castle, Jamestown, St. Helena.

St. Helena Records. Original manuscripts in The Archives, The Castle, Jamestown, St. Helena.

Stuiver M, Polach HA. 1977. Discussion: reporting of ${ }^{14} \mathrm{C}$ data. Radiocarbon 19(3):355-63.

Tanaka N, Monaghan MC, Rye DM. 1986. Contribution of metabolic carbon to mollusc and barnacle shell carbonate. Nature 320(6062):520-3.

Ward GK, Wilson SR. 1978. Procedures for comparing and combining radiocarbon age determinations: a critique. Archaeometry 20(1):19-31. 